\title{
Türk Maarif (Eğitim) Şûralarında Tarih Eğitimi
}

\author{
Funda ALASLAN* \\ Marmara Üniversitesi, Eğitim Bilimleri Enstitüsü, Ortaöğretim Sosyal Alanlar Eğitimi \\ Bölümü, Göztepe Kampüsü, Kadıköy / İstanbul / Türkiye
}

\section{Doç. Dr. Ahmet ŞİMŞEK}

Sakarya Üniversitesi, Eğitim Fakültesi, Ortaöğretim Sosyal Alanlar Eğitimi Bölümü, Hendek / Sakarya / Türkiye

\section{Şenel ÇAMDEVİREN}

Sakarya Üniversitesi, Eğitim Bilimleri Enstitüsü, Eğitim Bilimleri Bölümü, Program Geliştirme ABD, Hendek / Sakarya/ Türkiye

\section{Özet}

Cumhuriyetin kurulmasıyla birlikte yeni rejime uygun nesillerin yetiştirilmesi düşüncesi doğmuştur. Bunun için yeni kültür ve eğitim politikaları benimsenmiştir. Bu gelişmelerde dil ve tarih alanında toplanan kongreler kadar maarif şûraları da etkili olmuştur. Bu çalışmada 1939-2010 yılları arasında toplanan Maarif Şûralarında (Millî Eğitim Şûraları) tarih eğitimine yönelik alınmış kararların, döneme ve günümüze yansıması incelenmeye çalışılmıştır. Çalışmada belgesel tarama modeli kullanılmıştır. Şûralarda ele alınan konuların dökümü ve söylemlerin analizi yapılmaya çalışılmıştır. Cumhuriyet tarihinde $18 \mathrm{kez}$ Maarif/Millî Eğitim Şûrası toplanmış olmasına rağmen sadece 1943, 1949, 1974, 1982 ve 1988 yıllarında tarih eğitimine

* Sorumlu Yazar. Tel: +902627229410Ｅ-posta: alaslan.funda@gmail.com 
ilişkin görüşmeler yapıldığına ve kararlar alındığına rastlanmıştır. Bu kapsamda Millî Eğitim Şûraları'nda tarih dersi ile ilgili olarak tarih müfredatı, tarih öğretmenlerinin eğitimi, tarih öğretiminin araçları, tarih dersi saatleri hakkında görüşmeler ele alınmıştır. Sonuç olarak, tarih eğitimini Cumhuriyetin erken dönemi iktidarının çok önemsediği, yeni yetiştirmek istediği vatandaş tipine uygun tarih eğitimi inşa ettiği görülmüştür.

Anahtar Kelimeler: Tarih eğitimi; Maarif şûrası; Tarih dersi.

\title{
Education of History in the National Education Councils
}

\begin{abstract}
With the establishment of the Republic, the idea to grow suitable generations for the republic has been born. To achieve this idea, new cultural and educational policies have been adopted. Within these improvements, national educational councils have been effective as well as congresses held in the area of language and history. In this work, the reflection of the decisions taken about the education of history in the National Education Councils held between 1939-2010, in regard to that period and also today have been evaluated. Document browsing methodology has been used in the work. List of subjects and discussions taken place in these councils have been tried to be documented and analysed. It has been observed that although these councils convened 18 times in the history of the republic, only those taken place in the years of 1943, 1949, 1974, 1982 and 1988 included discussions and decisions taken about the education of history. In this context, subject in regard to lesson of history such as the syllabus of history, training of teachers of history, tools needed in the educatino of history, course hours needed for the lesson of history have been discussed at those national education councils. In conclusion, it has been observed that the government of the early period of republic paid much attention to the education of history and constructed an education of history in order to grow a new type of citizens which were the main focus of bringing up.
\end{abstract}

Keywords: Education of history; The national education comittee; Lesson of history. 


\section{Extended Summary}

With the establishment of the republic, the idea of growing up new generations suitable for the new regime has been born. For this reason, new culturel and educational policies are adopted. According to this new understanding of education, schools and context of the lessons tought in the schools as well as organization of textbooks became a current issues. The first serious action to shape the understanding of in the field of education new Turkish Republic was taken with the meeting of the Scientists Board (Heyet-i İlmiyye). But the efforts planned to determine new goal for the whole education system were realized with the Law on Unification of Education (Tevhid-i Tedrisat Kanunu) in 1924. With the rule of "the Law on Unification of Education” (Tevhid-i Tedrisat Kanunu), the qualification of new education system became clearer. This law was based on to grow up acceptable citizens loyal to the republic, instead of raising "vassals" loyal to the family of dynasty (Üstel, 2004).

Afterwards, "1924 Primary Schools Syllabus" (1924 İlk Mektepler Müfredatı) was prepared and applied beginning from 1927-1928 education year. The efforts to create a modern - national state and society after 1928, it was observed that national recovery was the basics of the transformations especially in the field of culture (Toprak, 2012, s.11). One of the important attempts was to establish “Society for the Study of Turkish History” (Türk Tarihi Tetkik Cemiyeti) in 1931 and the other one was to form "Society for the Study of Turkish Language” (Türk Dili Tetkik Cemiyeti) in 1932. Cultural 
policies such as “Turkish History Thesis” (Türk Tarih Tezi) and “Sun-Language Theory” (Güneş-Dil Teorisi) were parts of this process.

\section{Purpose}

The purposes for writing a Turkish History Thesis (Türk Tarih Tezi) was to increase the conscious of being a nation. In 1930, the book called Main Lines of Turkish History (Türk Tarihinin Ana Hatları) as prepared, then the books named History I, II, III, IV were written by the Society for the Study of Turkish History (Türk Tarihi Tetkik Cemiyeti) and taught in high schools beginning from 1931-1932. It was written in the coming years another book named Introduction to Main Lines of Turkish History (Türk Tarihinin Ana Hatlarına Methal) and other course books for primary and elementary schools (Çapa, 2002, s.49).

In this period, education was designed and used as an ideological instrument to grow "acceptable” citizen to the new republic. In this respect the education was planned to "create a modern nation" in general, and specifically to give a "Turkism" education within history lessons.

The First National Education Councils in Turkey was founded in order to develop policies based decisions taken by the ministry of Education as well as to search for instruction schedule and regulations, rules, plans of legislation. In the beginning, it is named as the Scientists Board, then it is called as the National Education Councils in 1939. 


\section{Methods}

In this work it is tried to search the decisions of the National Education Councils which were held between 1939-2010. Documentary scanning method was used in this work. According to Karasar, documentary scanning model means that are held and "collecting data existing records and documents” (Karasar, 2005, s.183).

Some criteria are determined during the examinations of official reports. It is tried to analyze the subjects discussed in the council. The basic points of this work are here below:

1- Which points of the education of history were emphasized by the National Education Councils?

2- How did the the National Education Councils effect in shaping the education of history at that time?

3- How were the subjects in regard to the education of history (syllabus, course books, materials) handled by the National Education Councils?

\section{Results}

Although the National Education Councils convened 18 times in the history of The Republic, it was seen that only in the councils held in 1943, 1949, 1974, 1982 and 1988 that this discussions were done and decision were taken in regard of the education of history. In this context, subject in regard to the syllabus of lesson of history training of teachers of history, tools needed in the education of history, course hours needed for the lesson of history have been discussed. 
Discussions and decisions about the education of history were firstly and thoroughly seen at the second National Education Councils. It is remarkable that during the aforementioned councils's meetings on the education of history, the Second World War was going on. During these years together with the "Nationalism” ideology hasn't been entirely left behind, the weight of the idea has been given unto "Humanism” and as a cultural attempt; the main goal of the education has been focusing on bringing up "the good citizen" in the context of "Turkish Nationalism”. In this council, the purpose has been almost to revise completely the syllabus of education of history, course books and training of teachers. Striking decisions have been concluded in this council. In the first half of 40 's, while the children-centred understanding began to dominate the literature, these councils discussed how the books and syllabus should be structured to ensure being viable to students' acknowledging growth. Same discussions took place on the fourth council. This may seem as the decisions concluded on these council have not been taken into action until after the fourth council has been convened.

The point that must be emphasized is that the discussion on writing of history books in accordance with the Intellectual Cooperation Commission of the league of Mations dictations. This subject was proposed by Sadrettin Celal Antel, but it has been rejected by Enver Ziya Karal, with the reason of history that "Big Chief”s advices have been effective on the writing process of the books of history. On this period, politics began to be polarized into different extremities and discussions based on Turkism-Humanism can be observed. 
Synchronic History Tables have been proposed for usage on this second council meeting and teaching technologies have been encouraged to be used by teachers such as picture collections, projection devices and radios on the same period.

Training of teachers of history has been first discussed in these councils and it has been proposed that teachers of history should be included in a different syllabus than that of historians. Even today, this distinction has not been fully applied and it can be seen that the belief for teachers of history need to have a different syllabus does not fully exist. Pedagogic formation, which is insufficient is being given to graduates in order to make them historians.

As a conclusion, it can be said that among all the councils convened throughout the history of the republic, the second council is the most important one as for education of history. Most of the discussions, decisions and conclusions taken in this council have been applied, until today and kept it validity. But, history and education of history, revolving world order, researches, new theories, expectations from the "citizens" and politicians who shape the political history.

\section{Giriş}

Cumhuriyetin kurulmasıyla yeni oluşan rejime uygun nesillerin yetiştirilmesi düşüncesi doğmuştur. Osmanlıcılık ve İslamcılık çerçevesinde şekillenen önceki devlet politikasının öngördügü vatandaş tipinin yerine Cumhuriyete bağlı bireylerin yetiştirilmesi için yeni kültür ve eğitim politikaları benimsenmiştir. Bunlardan eğitime ilişkin olarak okullarda okutulan derslerin içeriğini belirleyen program ve ders kitaplarının dü- 
zenlenmesi gündeme gelmiştir. Bu çerçevede Cumhuriyet ilan olunmadan önce, 1921 yılında bir eğitim müfredatını düzenlemek için toplantılar yapılmışsa da, bu yıllarda tüm yoğunluğun Millî Mücadele'ye verilmesinden dolayı "kökten" sayılabilecek yeni bir uygulamaya gidilmeyip eski programların uygulanmasına, ders kitaplarının okutulmasına devam edilmiştir.

Türkiye Cumhuriyeti'nin eğitim alanında anlayışını biçimlendiren kurullardan ilki 15 Temmuz-15 Ağustos 1923 tarihlerinde Ankara'da toplanan Maarif Şûralarının öncüsü sayılabilecek olan Birinci Heyet-i İlmiye'dir. Bu toplantı ile Türk eğitim sisteminin yeni hedeflerinin belirlenmesi yönünde çalışmalara başlanmış, ancak tüm bu girişimler reel anlamda 1924 Tevhid-i Tedrisat Kanunu ile hayata geçirilebilmiştir. Tevhidi Tedrisat Kanunu ile yeni eğitimin niteliği netleşmiş, hanedan ailesine "sadık kullar" yetiştirmek yerine Cumhuriyete bağlı "makbul vatandaşlar" yetiştirilmesi esas alınmıştır (Üstel, 2004). Ancak bu dönemde yapılan yenilikler Meşrutiyet döneminde "Lisan-1 Osmanî" ve “Tarih-i Osmanî” olarak okutulan derslerin “Türk Dili” ve "Türk Tarihi” başlıkları çerçevesinde düzenlenmesiyle sınırlı kalmıştır (Aslan, 2012, s.334). Bu kanun ile yapılan değişikliklerden ve belirlenen eğitim ve eğitim hedeflerinden sonra eğitim kurumlarında verilecek derslerin içeriğinin belirlenmesi amacı ile 23 Nisan-1 Mayıs 1924 tarihleri arasında İkinci Heyet-i İlmiye toplanmış ve Cumhuriyet tarihinde ilk defa ilköğretim ve orta öğretim için müfredat programları hazırlanmıştır (Aslan, 2011, s.753-754).

Yeni kurulan Cumhuriyet ile eski rejime ait programlar arasındaki 
uyumsuzluğu gidermek üzere yapılan "1924 İlk Mektepler Müfredat Programı" 1927-1928 ders y1lı itibariyle uygulamaya konmuştur. $\mathrm{Bu}$ programa göre ilköğretim tarih dersi programı 3 bölümden oluşmuştur. İlki hedeflerin planlanmasıdır. 2. ve 3. madde döneme göre ileri bir görüş ve uygulama olan disiplinlerarası yaklaşımdan yararlanma bağlamında “derslerin coğrafya dersleri ile paralel yürütülmesidir”. Bir diğer madde ise "medeniyet tarihine önem verilmesi, derslerin isim ve tarihlerle boğulmaması ve görsellerden ve tarihî eserlerden yararlanılması" şeklindedir. Ancak tarih öğretmenlerinin geleneksel yaklaşımdan vazgeçemeyişleri, ders kitaplarının ve araç gereçlerini yetersizliği bu amaçların gerçekleştirilmesini mümkün kılamamıştır (Aslan, 2012, s.338).

1928'den sonra gerçekleştirilen modern-ulus devlet-toplum inşa etme çabalarında millîleşme gayretlerinin, yapılan kültür alanındaki inkılâpların özünü oluşturduğu görülür (Toprak, 2012, s.11). Bunda 19. yy. sonlarında Rus Çarlığı'ndan Osmanlı Devleti'ne göç eden Türk dilli sığınmacılarının büyük katkısı olmuştur. Bu sığınmacılar sayesinde Cumhuriyet bireylerinin eski (heterojen) Osmanlı kültürünün etkisinden kurtularak yeni (homojen) bir Türk kimliği inşa edilen yeni kimliği kazanma çalışmalarına hız vermek ile mümkün olmuştur (Copeaux, 2006, s.30). Bu çerçevede yapılan önemli inkılâplardan biri 1931'de Türk Tarihi Tetkik Cemiyeti'nin, diğeri ise 1932'de Türk Dilini Tetkik Cemiyeti’nin kurulmasıdır. Bir kültür politikası olarak “Türk Tarih Tezi”nin ve “Güneş Dil Teorisi”nin ortaya atılması da bu sürece dâhil gelişmelerdendir.

Türk Tarih Tezi'nin yazılması ile hız kazanan bu yeni kültür çalışmalarında amaç, ulus olma bilincini soyut, Asyatik bir Türkçülük çerçe- 
vesinde içe dönerek aşllamaktır. Bu dönemde Türklerin tarihteki yerinin önemine dikkat çekilen çalışmaların desteklendiği, “Türklerin tarih çağlarını açtıkları ve kapattıkları” yönünde anlayışın ele alınmaya başlandığı görülür. Batı'nın küçümseyici etkisinden uzak bir şekilde Türk kimliği tanımlamayı amaç edinen başta Türk dilli Rus göçmeni Yusuf Akçura olmak üzere dönemin aydınları çeşitli çalışmalar yapmıştır (Copeaux, 2006, s.43). Bu çerçevede Akçura tarafindan da eleştirilen eski Fransız eksenli eski kitapların yerini alacak tarih ders kitaplarının yazılmasına başlanmış, 1930 yılında Türk Tarihinin Ana Hatları adlı kitap hazırlanmıştır. Sonrasında Türk Tarihi Tetkik Cemiyeti tarafından yazılan Tarih I-II-III-IV adlı kitaplar 1931-1932 y1lından itibaren liselerde okutulmuştur. Daha sonraki yıllarda ise Türk Tarihinin Ana Hatları'na Methal başta olmak üzere lise tarih kitapları kaynak alınarak ilk ve orta öğretim için de tarih ders kitapları yazılmıştır (Çapa, 2002, s.49).

Bu dönemde yeni Cumhuriyete, yeni topluma "makbul” vatandaşlar yetiştirmek için eğitimin ve okullaşmanın ideolojik bir araç olarak kurgulanması söz konusudur. İnkılâplar yoluyla gerçekleştirilen değişimin halka benimsetilmesi için ilkokul seviyesinden başlamak üzere ortaokul ve lise programları-ders kitapları üzerinde ciddi mesai harcandığı görülür. Buradan hareketle genelde modern bir "ulus ol(uştur)ma" esasına dayalı bir eğitim; özelde ise "Türkçülük" esasına dayalı tarih eğitiminin verilmesi planlandığı söylenebilir. Bu çerçevede yapılan tarih ve dil kongreleri kadar Maarif Şûralarında tartışılan konular ve alınan kararların da dikkate değer olduğu çıkarsanabilir. Cumhuriyetin, tarih eğitimine yüklemiş olduğu misyonu ve tarih eğitiminin nasıl olması gerektiği ile ilgili birikimi 
Maarif Şûralarından takip etmek de mümkündür.

Türkiye’de Maarif Vekâletinin (daha sonrasında ismi Millî Eğitim Bakanlığıdır) alacağı kararlara ilişkin politikalar geliştirilmesine imkân tanıyan Maarif Şûrası, her derecedeki eğitim kurumlarının öğretim programlarını ve bakanlıkça gerekli görülen yönetmelik, tüzük ve kanun tasarılarını incelemek, bakanın onayına sunulacak kararları almak üzere kurulmuştur. Öncüsü Birinci Heyet-i İlmiye adı altında 1923’te toplanan kurul daha sonraları 1939'da asıl hüviyeti çerçevesinde Maarif Şûrası ve Millî Eğitim Şûrası isimlerini almıştır. Talim ve Terbiye Kurulu ile birlikte bu şûralar, Cumhuriyet dönemi boyunca eğitimin biçimlenmesinde çok önemli girişim ve katkılarda bulunmuştur. Bu katkıların yanında, şûralarda görüşülen konuların, toplumun her kesiminden gelen grupların eleştirilerine sunulması, toplumda demokratik anlayışın pekiştirilmesine katkı sağladığı gibi program geliştirme çabalarını da destekler mahiyettedir.

\section{Yöntem}

Bu çalışmada 1939-2010 y1lları arasında toplanan Maarif Şûralarında (Millî Eğitim Şûraları) tarih eğitimine yönelik alınmış kararların ne olduğu, neyi öngördüğü, bunun dönemi için ne anlama geldiği ve günümüze yansımasının nasıl olduğu sorularına cevap verilmeye çalış1lmıştır. 1939'dan 2010 yılına kadar yapılan şûraların MEB tarafından yayımlanmış tutanakları incelenmiştir. Çalışmada belgesel tarama modeli kullanılmıştır. Belgesel tarama modeli Karasar'a göre; "varolan kayıt ve belgeleri inceleyerek veri toplamaya” (Karasar, 2005, s.183) denir. 
Çalışmada Millî Eğitim Şûralarına ilişkin yayımlanmış tutanaklar (kitaplar) incelenirken bazı ölçütler belirlenmiş, şûralarda ele alınan konuların dökümü ve söylemlerin analizi yapılmaya çalışılmıştır. Çalışmada kullanılan dayanak noktaları şu şekildedir.

1. Millî Eğitim Şûraları tarih eğitiminde hangi noktalara vurgu yapmiştır?

2. Millî Eğitim Şûraları'nın dönemin tarih eğitiminin şekillenmesinde nasıl etkileri olmuştur?

3. Millî Eğitim Şûraları’nda tarih eğitimini ilgilendiren konular (müfredat, ders kitapları, materyaller...) ne şekilde ele alınmiştır?

Tarama aşamasında 1939-2010 yılları arasında toplanan Maarif Şûralarında alınan kararlar ve benimsenen söylemler tek tek incelenerek belirlenen noktalar çerçevesinde değerlendirilmiştir. Tarama aşaması tamamlanınca veriler belirlenen noktalarda sınıflandırılmış ve elde edilen verilerden seçilen söylemler, söylem analizi tekniği ile örnek olarak işlenmiştir.

\section{Bulgular}

Cumhuriyet tarihinde 18 kez Maarif/Millî Eğitim Şûrası toplanmış olmasına rağmen sadece 1943, 1949, 1974, 1982 ve 1988 yıllarında tarih eğitimine ilişkin görüşmeler yapıldığına ve kararlar alındığına rastlanmıştır. Tarih eğitimi ile ilgili yapılan görüşmeler ve alınan kararlara ilk ve yoğun olarak 1943 yılında toplanan İkinci Millî Eğitim Şûrası'nda rastlanmıştır. Sözü edilen şûranın İkinci Dünya Savaşı'nın 
sürdüğü yıllarda yapılmış olması ve burada tarih derslerine ve eğitimine özellikle odaklanılması dikkate değerdir. Bu yıllarda "millîlik" düşüncesinden tamamen vazgeçilmemişse de ağırlık "hümanizm” düşüncesine verilmiş, bir kültür girişimi olarak Türk hümanizması yaratma çerçevesinde bu yıllarda eğitimin temel hedefi "iyi yurttaş" yetiştirmek olmuştur. Bu kapsamda Millî Eğitim Şûraları'nda tarih dersi ile ilgili olarak tarih müfredatı, tarih öğretmenlerinin ĕgitimi, tarih ögretiminin araçları, tarih dersi saatleri hakkında görüşmeler ele alınmıştır.

\section{Bulgu 1. Millî Eğitim Şûralarında Tarih Müfredatı}

Maarif Şûralarında tarih programlarının düzenlenmesine ilişkin dile getirilen görüsslerin; 1) öğrencilerin yaş, pedagojik durum ve duygularının dikkate alınması, 2) medeniyet tarihine ă̆ırlık verilmesi, 3) ilkokullarda tarih ders içeriğinin çok gereksiz detaylardan arındlrılması, 4) Türk tarihinin bütünlüğü içinde olayların sebep ve sonuç ilişkilerini ortaya koyacak ve millî bir tarih şuuru ve perspektifi kazandıracak şekilde ele alınmasına ilişkin olduğu görülmüştür (II., IV. ve XII. Maarif Şûraları). Bunlara ayrıntılı olarak bakıldığında ilk olarak İkinci Millî Eğitim Şûrası'nda tarih dersi müfredatı ile ilgili olarak görüş bildiren Ankara Gazi Terbiye Enstitüsü Ruhbilim Öğretmeni Ziya Talat olduğu görülür. Talat, hem öğretim programlarında hem de tarih öğretiminde öğrencilerin yaş, pedagojik durum ve duygularının dikkate alınması gerektiğini belirterek;

“Bütün ders müfredatlarında olduğu gibi tarih derslerinin de müfredatında da ögrenciler cansız bir varlık olarak düşünül- 
mekte, öğrencinin zihnî gelişimi ve yaşı dikkate alınmadan program hazırlanmaktadır. Bu da derslerde verimi düşürmektedir. Çocuklar ilk ve ortaokulda gözleriyle gördüklerine ve kulaklarıyla işittiklerine inanır, lisede ise hisler ve duygularla hareket eder. Bu açıdan ortaokul müfredatındaki aynı konuların lisede de genişletilerek tekrarlanması doğru değildir... İnsan ruhunu merkez ve bilgiyi onun etrafinda dönen bir peyk yapalım.” şeklinde görüşlerini belirtmiştir.

Piaget'nin bilişsel gelişim kuramı çerçevesinde değerlendirilebilecek Talat'ın bu söyleminde, halihazırda öğrencinin gelişimine uygun müfredat hazırlanmadığı, bu durumunda öğrencilerin soyut bir ders olan tarihi anlamada zorluk çektikleri öne sürülmektedir.

Tarih programlarının düzenlenmesine ilişkin diğer bir öneri ise Prof. Dr. Ömer Lütfi Barkan'a aittir. Programın içeriğinin medeniyet tarihi ağırlıklı olması gerektiğine ilişkin görüş bildiren Barkan şunları dile getirmiştir:

“...Son yıllarda Türkiye’de gerek tarih anlayış tarzımızda ve gerekse muhtelif sınıflara ait tarih kitaplarının hazırlanış usullerinde bazı yenilikler yapılmıştır. Şu halde tarih program ve kitaplarında yapılması gerekli değişiklikler ufak tadil ve tashihler değil, esaslı reformlar olmalıdır. Tedrisat sistemimizde böyle mühim bir boşluğun doldurulması için gerçekleştirilmesini bir ülkü bildiğimiz bu reform ise liselerimizde tarih derslerini çok geniş manada bir medeniyet tarihi şeklinde okutabilmek için lüzumlu tedbirlerin alınmasından ibarettir. Medeniyet tarihi müf- 
redatlara yansitılmall, hadiselerin kültür, sosyal, iktisadi sebepleri ve sonuçları anlatılmalı ve yetişecek tarih ögretmenleri de bu tarzda eğitim almalıdır."

Barkan'ın bu kararının oluşmasındaki etmenlere bakıldığında 1924 yılında hazırlanan müfredatta liselerde okutulan tarih ders kitapları Avrupa merkezli tarih öğretimini desteklemesi (Çapa, 2002, s.42) ve Tanzimat'tan 1925 yılına kadar yazılan ve okutulan tarih ders kitapları Fransa ekseninde (Akçura, 2011, s.50) olması yanında, 1932 yılında Birinci Türk Tarih Kongresi'nde ortaya atılan Türk Tarih Tezi’nin öğretime yansıtılma kaygılarının olduğu söylenebilir. Barkan'ın yukarıdaki görüşlerinden hareketle 1943 yılına gelindiğinde tarih ders kitaplarında yapılan yeniliklerin istenilen düzeyde olmadığı, eksikliklerin devam ettiği de anlaşılmaktadır.

Tarih ders programı ve kitaplarına ilişkin diğer bir görüş de 1949 tarihinde Dördüncü Millî Eğitim Şûrası'nda ise İhsan Üngüt tarafından dile getirilmiştir. Üngüt, ilkokullarda tarih kitaplarının çok gereksiz detaylarla dolu olduğunu, öğrencilere bu kadar yüklü programın verilmemesini ve komisyonun hazırladığı raporda da buna çözüm getirilmediğini söyle dile getirmiştir:

"Bu müfredat ve bu kitaplar çocuklarımıza asla bir tarih zevki ve tarih sevgisi vermiyorlar. Bu antipati lisenin son sinıfina kadar da devam ediyor. Ĕger bu müfredat programını tetkik edecek olursak görürüz ki lisenin üç sınıfinda vermek istediğimiz malumatı, ilkokulun iki sınıfında vermeye çalışıyoruz. Biz ĕ̆er tarihi ilkokullarda böyle kül halinde okutmaya kalklşırsak, maddeten 
onlara bir şey öğretemeyeceğiz demektir... Bunun için mutlaka müfredat programını değiştirmeliyiz. Bunu ıslah etmek elimizdedir. Bundan sonra da çocukların anlayacağl ve seveceği şekilde güzel kitaplar yazmalıyı... Ĕger sevdiremezsek okutama$y ı z \ldots$

Üngüt'ün görüşlerinde çocukların anlayabileceği ve sevebileceği bir tarih eğitiminin gerekliliğine dikkat çekilmesi önemli sayılmalıdır. Zira 1949 gibi eğitim programlarının düzenlenmesinde fazlasıyla "konu merkezli" davranılan bir dönemde "öğrenci merkezli” bir program ve eğitim anlayışının temel gereksiniminin tarih dersi için dile getirilmiş olması önemlidir. Bu durum tesadüfi de görülmemelidir. Zira ülkemizde Kemal Kaya'nın 1939'da Alman eğitimci Eric Andraess’ten çevirdiği "Çocuğa Uygun Tarih Tedrisatı" adlı kitap yanında bundan büyük ölçüde etkilenerek Fuat Baymur'un 1941'de yayına hazırladığı “Tarih Öğretimi” adlı çalışmasının çocukların gelişimsel özelliklerinin onların tarih öğrenmeleri üzerindeki etkisini ele almaları bakımından göz ardı etmemek gerekir. Her ne kadar bu eserlerde daha 1940'larda bile tarih öğretiminin nitelikleri arasında öğrencilerin gelişimsel seviyelerinin dile getirilmiş olmasına rağmen gerçekten "öğrenci merkezli" bir öğretim programı için 2005 yılını beklemek gerekmiştir. Bu çerçevede Üngüt'ün 1949 'da dile getirdiği önerilerin bugün bile çağdaş tarih eğitimi açısından geçerli olduğu söylenebilir.

Diğer bir görüş ise 1988'de XII. Millî Eğitim Şûrası'nda ele alınan tarih derslerinin, “Türk tarihinin bütünlügüün̈, “olayların sebep ve sonuç ilişkilerini ortaya koyacak ve tarih şuuru ve perspektifi ka- 
zandıracak şekilde ele alınması"na karar verilmesidir. 12 Eylül Askerî Darbesi sonrasında toplanan bu şûrada özellikle Türk tarihine vurgu yapılması ve öğretiminin sebep-sonuç ilişkisi içinde verilmesinin kararlaştırılması dönemin hâkim politik havasından kaynaklanmıştır. Bilindiği üzere 1980’li yıllar, siyasi çalkantılar ile geçen bir dönemden sıyrılarak yeni bir politik sürecin başlaması, beraberinde de yeni ve sisteme uygun düşünen bireylerin yetiştirilmesini ortaya çıkarmıştır. Bu dönemde a-politik bir eğitim yanında "romantik" bir biçimde gerçekleştirilen "şanlı tarih" vurgusunun ağırlıklı olarak Türk askerî ve siyasî başarılarının kronolojik olarak sıralamasıyla tarih müfredatının fazla pragmatik biçimde kurgulanması söz konusu olmuştur. Bunda dış siyasada yaşanan soğuk savaş ve kutuplaşma sürecinde Sosyalist Sovyet Bloğuna karşı Kapitalist Batı Bloğunda yer almanın getirdiği "hamasilik", "romantikliğin" de askerî başarılarla yüklü bir tarih eğitimi kurgusunu ön plana çıkarmada rolü olduğu söylenebilir.

\section{Bulgu 2. Millî Eğitim Şûralarında Tarih Dersi Kitapları}

Tarih ders kitapları ile ilgili İkinci Millî Eğitim Şûrası'nda görüşmelerin yapıldığı görülmektedir. $\mathrm{Bu}$ şûrada tarih ders kitaplarının barış eğitimine katkı sağlayacak şekilde yeniden düzenlenmesi teklifini Sadrettin Celal Antel, Milletler Cemiyeti'nin Cooperation Intellectuelle (Entelektüel İş Birliği) komisyonunun tespit ettiği esasları hatırlatarak yapmıştır. Antel tarafından, tarih ders kitaplarından milletleri birbirine karşı kin ve intikam hislerine yönelecek şekilde olan kısımların çıkarılması ve öğrencilere okutulacak tarih ders kitaplarının Cooperation Intellectuelle tarafından belirlenen şartlarda düzenlenmesi 
teklif edilmiştir (MEB,1991, s.224). Bu şartlar:

“1.Sadece gerçek olan olayları yazmak

2.Herkes tarafindan kabul edilen hukuk prensipleri dışında bir devletin suçluluğu ve suçsuzluğu hakkında kesin hüküm vermemek

3. Yabancı bir millete karşı doğrudan ya da dolaylı olarak nefret, kin ve intikam hislerini aşılayacak sözler kullanmamak

4. Savaşlar hakkında bütün gerçekleri söylemek, savaşın zararlı niteliği, felaketli sonuçları hakkında açıklamalar yapmak, savaşın getirdiği barışın devamlı bir barış olamayacă̆ fikrini aşılamak

5. Milletler arasındaki ilişkileri barış yoluyla çözmeye çalışan örgütlerden söz etmek

6. Sosyal, ahlâkî, askerî erdemleri yalnız bir millete indirgememek" (akt; Safran ve Ata, 1996, s.13).

Yukarıda belirtilen fikirlerinden dolayı Sadrettin Celal Antel; Yavuz Abadan, Necati Tacan, Cemil Bilsel ve özellikle Hasan Âli Yücel'in eleştirilerine uğramıştır (Safran ve Ata, 1996, s.13).

İkinci Maarif Şûrası'nda farklı bir görüş ise Ankara Dil ve Tarih-Coğrafya Fakültesi Tarih Profesörü Enver Ziya Karal'dan gelmiştir. Karal'a göre tarih ders kitaplarının yazımında önemli hatalar yoktur. Çünkü şûranın toplandığı yıl itibariyle (1943) liselerde okutulan tarih ders kitapları Avrupa tarih kitaplarının yazılışında kullanılan metotlar gözetilerek yazılmıştır. Ayrıca tarih kitapları yazılırken Milletler Ce- 
miyeti'nin tespit etmiş olduğu maddelerden yararlanma lüzumu görmemişlerdir. Çünkü tarih görüşleri ve tarih ders kitabı hakkındaki görüşleri "büyük şefler"i tarafından izah edilmiştir. Daha önce, 1932 yılında Paris'te toplanan Uluslararası Tarih Tedrisatı Kongresine Türk Tarihi Tetkik Cemiyeti'ni temsilen katılan Genel Sekreter Muzaffer Göker okutulan tarih kitaplarında diğer milletleri düşmanlığa sevk edecek fikir ve konular içermediğini belirterek, diğer ülkelerin ders kitaplarında bulunan bu tarz söylemlerin çıkartılmasını temenni etmiştir (Çapa, 2002:54) Antel'in görüşlerine şiddetle karşı çıkan Hasan Âli Yücel de Kurtuluş Savaşı yıllarında Milletler Cemiyeti'nin hazırlamış olduğu raporda tutarsızlıklar olduğunu belirterek Enver Ziya Karal ve Muzaffer Göker'in söylemleri ile paralellik gösteren bir konuşma yapmıştır. Ancak üç sene sonra 1946 yılında Türkiye adına Entelektüel İş Birliği Komisyonunun devamı niteliğindeki ders kitaplarındaki düşmanlıkları körükleyecek ifadelerin çıkarılmasını içeren UNESCO Sözleşmesi'ni Hasan Âli Yücel imzalamıştır (Safran ve Ata, 1996, s.13).

1960 yılına gelindiğinde ise Afet İnan tarih ders kitapları ile ilgili görüşlerini şu şekilde belirtmiştir. "Eğer okul programlarında tarih ögretiminde olayların kronolojik bir sıra hâlinde verilmesi dışında özellikle uygarlık kurumlarına yer verilirse, millî karakterler daha çok meydana çıkarak barışçı fikirlerin doğmasına ve gelişmesine yardım eder.” İnan'ın bu söylemiyle Entelektüel İş Birliği Komisyonunun görüşlerine paralel bir tutum sergilediği görülmektedir. Ancak 1946 yılında tarih ders kitaplarından düşmanlık barındıran konuların ve söylemlerin çıkarılması yönünde sözleşme imzalanmış ve sorunun 
çözümü konusunda büyük ilerlemeler kaydedilmiş olsa dahi, Türkiye'deki 9 ve 10. sınıf lise tarih güncel ders kitaplarında bile "ötekileştirme" ve "düşmanlık" barındıran konu ve söylemlerin kısmen de olsa devam ettiğini söylemek mümkündür (Şimşek ve Koca, 2012).

Günümüzde tarihte nesnellik konusu hâlâ tartışılmaya devam ederken, Karal, İkinci Maarif Şûrası'nda Türk tarih ders kitaplarının durumunu şu sözleri ile değerlendirmiştir: “...Türk tarihi yazımı yapılırken mümkün olduğu kadar objektif davranılmıştır, konular üzerinde eksiklik varsa bu da kaynaklar yeterli olmadı̆̆ içindir... Yazılan tarih kitaplarında en iyi şekilde ilgili ölçülere uyulmuştur...” Karal'ın bu söylemi ile bahsettiği, Antel'in de dikkat çektiği Entelektüel İş Birliği Komisyonu tarafından altı maddede belirlenmiş tarih ders kitapları yazımı ile ilgili rapordur. Karal'a göre ders kitaplarının yazımında yukarıdaki maddelere uyulmasını gerektirecek bir durum söz konusu değilken, Antel bu maddelere dikkat etmenin önemini vurgulamaktadır. Ancak Antel'in bu konuda haklı olduğunu 1946 yılında UNESCO sözleşmesinin imzalanması ile anlamaktayız.

İkinci Dünya Savaşı yıllarında barış eğitimine yönelik bir karar alınması ve bu kararın tarih ders kitapları vasıtasıyla öğrencilere aktarılmak istenmesi olumlu bir gelişmedir. Barış eğitimine yönelik yapılmış olan programların ana başlıkları birbiriyle paralel düzeydedir. Buna göre, barış ve şiddetin doğasını anlama, bilgi düzeyinde (çatışmaları analiz etme, müzakere süreci, kişisel ve sosyal haklar ve özgürlükler, hak ve sorumlulukların anlaşılması) beceri düzeyinde, (iş birliği yapma, problem çözme, duyguları tanımlama, çatışma çözme, iş 
birliği ve etkin dinleme) tutum düzeyinde (kişisel saygı, kendini kontrol, hoşgörü, empati, sosyal sorumluluk, adalet ve eşitlik duygusu, kişilerin hak ve sorumluluklarına saygı) kazanılması gerekenler olarak sınıflandırılmıştır (Coşkuner, 2008, s.15). Ayrıca Antel, lise ve üniversite öğrencileri arasında yaptığı ankette öğrencilerin kronolojik tarih sorularına yeterli cevaplar veremediklerini ifade etmiştir (MEB,1991, s.226).

Aynı şûranın açı1ış konuşmasında ise dönemin Millî Eğitim Bakanı Hasan Âli Yücel de, tarih eğitiminin önemine vurgu yaparak konuşmasını şekillendirmiş, aynı zamanda tarih ders kitapları ile ilgili fikirlerini de belirtmiştir.

“Liseler için yazdırdığımız yeni kitaplarda millı̂ tarih görüşümüzü esas olarak, lisenin sahası dışında plan bilgiçlik endişelerinden uzak kalmaya, ifadenin dil inkılâbımıza uygun ve talebe tarafindan kolaylıkla anlaşılır olmasına, bahislerin tamamıyla klasik bir şekilde verilmesine, bahsin başına bir özet konmasına ve bu suretle talebenin o bahsi kavramakta güçlük çekmemesini temine, olaylar arasındaki siralanmanın kaybolmamasına, tarih kitaplarındaki bilgilerin diğer ilgili ders kitaplarıla denkleştirilerek bu dersin, çocukların diğer derslere vermeleri zaruri olan zamanı almamasına dikkat edilmiştir. Ayrıca imkân takdirinde çocukların şahsi araştırma ödevleri yapabilmelerine yardım etmek, klâsik tarih bilgisiyle memlekette yapılan tarih yayını arasinda bir münasebet temin edebilmek amaciyla de her kitabın sonuna bibliyografik bilgiler konmuştur. Buna ayrica tarih me- 
tinleri de ilâve edilecektir.”

Hasan Âli Yücel’in konuşmasında özellikle çocukların şahsi ödevleri üzerinde durmasının yaşadığı döneme göre oldukça ileri olduğunu dile getirmek mümkündür. Bu görüşün 1970’li yıllarda İngiltere'de "Yeni Tarih" anlayışı çerçevesinde kabul gören "doing history" (tarih yapma) yaklaşımı ile öğrencilerin pasif rolden sıyrılması, kanıta, araştırmaya ve sorgulamaya dayalı bir tarih eğitimi hedeflenmesiyle (Ata, 1999, s.2) paralellik arz ettiğini söylemek mümkündür. Aynı anlamı çağrıştıran "çocukların şahsi araştırma ödevleri yapabilmelerine yardım etmek" teklifinde ise yine öğrencilerin aktif olduğu öğretmen rehberliğinde kendi ilgi alanları doğrultusunda araştırmaya, kanıt kullanmaya ve analiz etmeye yönelik araştırma ödevleri hazırlamaları tercih edilmiştir. Bu çerçevede sunulan komisyon raporunda ilkokul tarih ders programının "çocukların anlayış ve ruh yapısına uygun olmadığ $\imath$ " ve bu programa göre yazılan ders kitaplarının tarih öğretimine elverişli olmadığı gerekçesiyle yeni bir ilkokul tarih kitabı yazılması istenmiştir.

Aynı şûrada, hazırlanacak ilkokul tarih kitaplarında uyulması gereken esaslar söyle belirtilmiştir:

1. Illkokul ve ortaokul tarih müfredat kitaplarl çocuğun fikir gelişimini, ruh yapısını, millî duygu ve karakterinin olgunlaşmasını sağlayacak, tarih sevgisini uyandıracak, olayları zaman içinde kavratacak bir değerde olmalıdır. Bu yukarıda da belirtildiği gibi pedagoji bilgisi ve görüşü açısından zamanına göre ileri bir görüş olarak kabul edilebilir. 
2. Bu kitaplarda olaylar ve gelişmeler ortaokul ve lise kitaplart gibi sıkı bir zincirleme bilgi veren şekilde olmalıdır. Tarihin belli dönemlerinde efsaneler, olay ve şahıslar seçilmeli ve bunlar çocukların ilgisini çekecek hikâye tarzında, sade fakat canlı bir dille belirtilmelidir. Lüzumsuz bilgiler içermemelidir. $\mathrm{Bu}$ madde de, döneminin genel eğitim uygulamalarından ileri olarak, tarihsel hikâye, biyografi, efsane-destan türünde edebî yazım türlerinin eğitimsel açıdan önemine dikkat çekmesi yönüyle önemli sayılabilir. Zira yapılan araştırmalarla tarihsel tahkiyeli eserlerin çocukların zihinsel gelişimlerine uygun olarak bir tarih eğitimi sunma açısından önemli birer tarih öğretimi materyali olabileceğini ortaya koymuştur (Şimşek, 2001, 2004). Tarihsel romanların ise özellikle ergenlerin okumayı sevmeleri ve sağlıklı bir tarih bilinci kazanmasında etkili olduğu, tarih konularının kavrayışını güçlendirdiği, bunlar aracılığıyla toplumda var olması istenen bazı kavramların yerleştirilmesi, bazı değerlerin telkin edilmesinin ve bazılarının da hicvedilmesinin mümkün olduğu görülmüştür (Ata, 2006, s.161; Şimşek, 2006, s.71).

3. Illkokul müfredat ve kitaplarının hazırlanmasında Türk Tarih Kurumunun bilimsel çalışmaları sonuçlarının ve bir de ilkokul eğitiminden başka bir eğitim görmeyerek hayata atılan yurttaşların millî duygularıla hayatı anlayış ve kavrayışlarını olgunlaştırmak amacı da göz önünde tutulmalıdır. Burada genel olarak Türk Tarih Kurumu'nun bulgu ve çalışmalarının öğrencilerin gerek müfredat gerekse kitap hazırlanmasında göz önünde bulundurulmasından bahsediliyor gibi görünse de asıl vurgu; millî 
bilincin 1932 y1lında biçimlenmeye başlamış olan Türk Tarih Tezi çerçevesinde inşa edilmesinin gereği üzerinde durulması ve bunun ilkokul düzeyinde de yansitılabilmesinin gereğine yöneliktir.

Raporda ortaokul tarih kitaplarının da tarih öğretiminin amacına uygun olmadığı, ortaokul 1., 2. ve 3. sınıf kitaplarının yeniden yazılması ve bazı bölümlerin kaldırılması istenmiş, kitaplar yazılırken gözetilecek temel esaslar olarak da; “kitapların ă̆ır konular içermemesi, tarih bilgisi verilirken millî meselelerin yanında dünya meselelerini de kavrayacak fakat millî ödevleri de anlayış ve özveriyle yapacak aydın bir yurttaş yetiştirilmesi" nitelikleri belirtilmiş, planların ve müfredatların hazırlanmasında bunlara uyulması istenmiştir. Lise tarih kitaplarında da aynı esasların dikkate alınması ve mesleki ve teknik okullardaki tarih kitaplarındaysa değişime gidilerek mesleki ve teknik okulların bünyesine, ihtiyaç ve amaçlarına uygun tarih kitaplarının yazılması istenmektedir. $\mathrm{Bu}$ teklif pedagojik açıdan akıllıca olarak nitelendirilmesine rağmen sözü edildiği gibi mesleki ve teknik okullarda kullanılacak tarih ders kitaplarının nasıl düzenleneceği, daha da önemlisi bu düzenlemenin hangi ihtiyaç ve amaçlar doğrultusunda yapılacağı belirsiz bırakılmıştır. Günümüzde bile teknik liselerde ve meslek liselerinde genel liselerde uygulanan tarih programının uygulandığı ve aynı tarih kitaplarının okutulduğu düşünülürse yukarıdaki önerinin gerçekleşememiş bir temenni olarak kaldığı anlaşılmaktadır.

22-31 Aralık 1949 tarihinde toplanan IV. Millî Eğitim Şûrası'nda ise başkanlığını Bakanlık Müfettişi olan Tarık Asal'ın yaptığı 54 kişi- 
den oluşan bir tarih eğitimi komisyonu toplanmıştır. Komisyon raporu sonucunda tarih ders kitapları ile ilgili olarak tarih (ve coğrafya) kitaplarının sonuna sözlük eklenmesi ve kitapların sonuna bibliyografya konulması önerisi getirilmiştir.

\section{Bulgu 3. Diğer Öğretim Materyalleri}

Tarih derslerinde kullanılması düşünülen öğretim materyallerine millî eğitim şûralarından sadece ikincisinde yer verilmiştir. Komisyon raporunda yer alan yardımcı materyaller; synchronik (senkronik) tarih tabloları, zaman tabloları, takvim çevirme kılavuzları, tarih atlasları, tarihsel resim koleksiyonları, projeksiyonda gösterilebilecek tarihsel nitelikli sanat eserleri, film ve radyodan yararlanma, öğretmen ve öğrenciler için yardımcı kitaplar ve Türkiye'deki arkeoloji mirası gösteren k1lavuzlar (envanterler) olarak sayılmıştır.

1. Synchronik (Senkronik) Tarih Tabloları: Şûra üyelerine göre verimli bir tarih eğitimi için "tarih olaylarının geçtiği yerlerde devletlerin genişlemesi haritalar üzerinde gösterildiği halde zaman fikrinin kavranması için talebenin elinde yardımcı vasıtalar bulunmamaktadır. Hâlbuki dünya tarihinde olup bitenleri kolaylıkla takip edebilmek için 'synchronik' levhalara ihtiyaç vardır. Bunlar öğrenciyi soyut rakamları ezberleme derdinden kurtaracaktır. Bunun için 'histomap' sistemi üzerine senkronik tablolar Maarif Vekilliğince hazırlatılmalıdır. Histomap, öğrencilerin dünyanın değişik yerlerinde gerçekleşen ve olayları eş zamanlı ve karşılaştırmalı olarak görebilecekleri bir materyaldir. 19. yüzyılda tarih eğitimindeki önemi kavranmış ancak Türkiye'de 1943 yılında derslerde yardımcı materyal olarak kullanılmasına karar 
verilmiştir. 1946 yılında Millî Eğitim Bakanlığı Eski Eserler ve Müzeler Genel Müdürü Hamit Zübeyr Koşar'ın başkanlığında “Tarih Öncesi ve Tarih Çağlarının Mukayeseli Zaman Tablosu" adıyla basılmıştır. Ancak basıldığı tarihten günümüze gelindiğinde histomapler yaygınlaşmamıştır. Nedeni de bilinememiştir. Bunlardan biri bu materyallerin Öğretim Teknolojileri ve Materyal Tasarım kitaplarında bulunmayışı ve öğretmen adaylarının histomapin varlığından habersiz olarak öğretmenlik mesleğine başlamaları olabilir (Ata, 2008, s.66-69).

Oysaki öğrenciler bu materyali kullanabildiklerinde inceledikleri bir tarihte dünyanın diğer yerlerinde neler olduğunu karşılaştırmalı olarak öğrenme şansına sahip olabileceklerdir. Günümüzde bile lise tarih ders kitaplarında zaman şeridi adı altında çağdaş devletlerin kuruluş ve y1kılış tarihlerini veren tablolar ile yetinilmektedir.

2. Dünya tarihinin önemli olaylarını, kültür hareketlerini mukayeseli bir tarzda göstermek için 'zaman tabloları' yaptırılmalıdır.

3. Tarih Atlasları: Mevcut atlaslar büyük boşluğu ancak kısmen telafi ettiği için tarihî vakalara sahne olan yerlerin ve devletlerin muayyen zamanlardaki yayılışını göstermek için daha iyi atlaslar vücuda getirilmelidir. Günümüzde de gerek tarih atlaslarının gerekse tarih haritalarının ihtiyacı karşıladığı ve yeterli olduğunu söylemek güçtür.

4. Hicri tarihi miladi tarihe çeviren kılavuzlar çoğaltılmalıdır.

5. Resim Koleksiyonlar1: Üniversite ve yüksek okullarda klasik sanat eserlerinin kopyalart ile dolu müzeler kurulmall, orta ve ilkokullarda ise büyütülmüs fotoğraf koleksiyonlarından faydalanılmalıdır. $\mathrm{Bu}$ müzelerin kuruluşunun günümüzdeki tarih eğitimi açısından da 
önemli olacağını söylemek mümkündür.

6. Tarihî şahıslar ve sanat eserlerini projeksiyon makinesi ile de göstermek mümkündür. Maarif müdürlüğü okul müzesi ilgili dairelerle iş birliği yaparak projeksiyon camları hazırlamalı ve bunları muayyen bir programa göre bir okuldan diğer okula yollamak işini düzenlemelidir. Eski anlamda projeksiyon makinelerine bugün gerek kalmamıştır. Zira bilgisayar teknolojisi tarihin görselleştirilmesinde öğretmenlere çok büyük imkânlar sağlamaktadır.

7. Film ve radyodan ders vasitası olarak okullarda önemle faydalanmak imkânları aranmalıdır. Radyo tarih derslerinde pek kullanılan bir cihaz olmasa da film bugün bile tarihin kavranması ve eğlenceli bir biçimde sunulması bakımından ziyadesiyle önemlidir. Tarihsel filmlerin çağdaş tarih öğretimi açısından çok önemli bir role sahip olduğu bilinmektedir (Öztaş, 2008).

8. Öğretmen ve talebeler için yardımcı kitaplar yazdırılması. $\mathrm{Bu}$ öneride ders öğretim materyallerinin çeşitliliğini sağlaması bakımından önemlidir. Ders kitabı dışında, öğretmen kılavuz kitabı ve öğrenci çalışma kitabına 2005 eğitim-öğretim uygulamaları sonrasında ulaş1labildiği ve tarih dersleri için bunun hâlihazırda uygulanmasının mümkün olamadığı düşünülürse teklifin zamanını aşan bir bakıştan kaynaklandığını söylemek mümkündür.

9. Memleketimizde mevcut arkeoloji eserlerinden istifade edilmesinin temini için vekillikçe bastırılmış olan kılavuzun tatbikine önem verilmesi (II. Maarif Şûrası, Çalışma Programı, Raporlar, Konuşmalar, 1943, s.203-204). Arkeolojinin buluntularının tarih dersle- 
rinde maddi birer gerçek materyal bağlamında önemi büyükken günümüzde bile tarih dersinin arkeoloji biliminde faydalanması söz konusu değildir (Şimşek, 2011).

Bu maddelere ek olarak Tevfik Sağlam tarafindan önerilen seyyar tarih müzesi uygulaması vardır. Daha önce Almanlar tarafindan Hıfzısihha Seyyar Tarih Müzesi olarak hayata geçirilen, Türkiye'de de faydalı olacağına inanılan bu müze tarih öğretmenlerinin, öğrencilerin ve halkın tarih üzerine ilgilerinin çekilmesi amaçlanmıştır. (II. Maarif Şûras1, Çalışma Programı, Raporlar, Konuşmalar, 1943, s.251). Bu düşüncenin de tarih müzeciliğgini öngörmesi bakımından ileri olduğunu, seyyar müze fikrinin ise daha önemli pedagojik bir öneri olduğunu söylemek mümkündür. Zira bugün tarih derslerinde müzelerin etkin bir biçimde kullanımı yanında kanıt temelli öğrenme faaliyetlerinin de rolü bilinmektedir (Ata, 2001; Doğan, 2008).

\section{Bulgu 4. Millî Eğitim Şûralarında Tarih Öğretmeninin Eğitimi}

Cumhuriyetin ilk yıllarında ders kitaplarını değiştirerek eski sistemin izlerini silmeyi hedefleyen anlayış, uygulamada tam anlamıyla başarılı olamayınca öğretmenler de eski bakış açılarından kurtulamamıştır (Aslan, 2012, s.337). Eğitim kurumlarında ders veren öğretmenlerin eğitimi 08-11 Haziran 1982'de toplanan XI. Millî Eğitim Şûrasında, 18-22 Temmuz 1988'de toplanan XII. Millî Eğitim Şûrasında görüşülmüştür. XI. Millî Eğitim Şûrası'nın toplanma amacı ve görüşülen/alınan kararlar öğretmen eğitimi ile ilgili olsa da tarih öğretmenlerinin eğitimi ile ilgili spesifik kararların alındığını söyleyemeyiz. 15-23 Şubat 1943 tarihinde toplanan II. Millî Eğitim Şûrası’nda 
ise tarih öğretmenlerinin yeterlilikleri görüşülmüştür. II. Millî Eğitim Şûrası'nda, Türklük eğitiminde tarih dersine düşen görevlerin öğrencilere aktarılması sürecinde ele alınacak yöntem ve araçları belirlemek üzere 21 Şubat 1943 tarihinde tarih öğretimi komisyonu toplanmış, doğrudan tarih eğitimi, tarih öğretmenleri, tarih öğretimi için gerekli yardımcı kaynaklar ve tarih öğretimi ile ilgili temenniler raporlaştırılarak aynı gün kurulda okunmuştur.

Ömer Lütfi Barkan tarafından “ögretmenlerin yetiştirilmesi meselesi de çok mühimdir. Bilhassa bizim yukarıda bahsettiğimiz şekilde bir tarih dersi okutacak olan ögretmenlerin fakültelerimizde tarih âlimlerine mahsus olan tedrisattan ayrl, hususi ve derli toplu bir rejime tâbi tutularak yetiştirilmeleri lazımdır. Bu gibilerin sanat tarihi, arkeoloji, içtimai ve iktisadi tarih, sosyoloji, felsefe ve edebiyat gibi dersleri muhakkak görmüş olmaları da ayrıca icap eder." görüşleri dile getirilmiştir. Bahsi geçen raporda, tarih öğretmenlerinin statülerinin düzenlenmesi, tarih öğretiminin alan bilgisine sahip öğretmenler tarafından yürütülmesi, tarih öğretmenlerinin yeni bilgileri öğrenmesi için kurslar açılması istenmiştir. 8-11 Haziran 1982 tarihinde gerçekleştirilen XI. Milli Eğitim Şûrası'nda öğretmen eğitimi ağırlıklı konular ele alınmıştır. Her öğretmenin ortak bir genel kültüre sahip olması öngörülmüştür. Türkçe ve Yabancı Dil eğitimi yanında Türk İnkılâp Tarihi dersinin de ortak ve zorunlu genel kültür derslerinden biri olması amaçlanmıştır. Bugün zorunlu olarak okutulan bu derslerin öğrencilere kazandırdıkları bakımından işlevlerinin tartışmalı bir halde olduğu söylenebilir. 


\section{Bulgu 5. Tarih Ders Saatlerinin Dağılımı}

Tarih ders saatlerinin düzenlenmesini de içeren, 24 Haziran-4 Temmuz 1974 tarihleri arasında toplanan IX. Millî Eğitim Şûrası'nda çok farklı konular üzerine görüşler belirtilmiş ve kararlar alınmıştır. Değişik eğitim programı uygulayan okullara ait ders dağılım çizelgelerinin yeniden düzenlenmesi de ele alınan konulardan biridir. Ders dağılım çizelgelerinde saatler itibariyle tarih ve tarih temelli derslerin oluşumu şu şekilde gerçekleşmiştir: Bütün orta öğretim programlarda ortak ders olarak okutulan derslerden biri olan tarih dersi 9. sinıflarda, T.C. İnkılâp Tarihi dersi ise 11. sınıflarda ikişer saat olarak belirlenmiştir. Ortaöğretim kurumlarında, yükseköğretime hazırlayan programlar ile hem mesleğe hem de yükseköğretime hazırlayan programlar için 9., 10. ve 11. sınıfların haftalık ders saatleri içinde tarih dersinin saat sayısı aşağıdaki gibi olması kararlaştırılmıştır. Buna göre; dil ve edebiyat, ekonomi ve sosyal bilimler, matematik-fizik, tabii bilimler alanlarında yüksek öğretime yönelik program uygulayan okulların 10. sınıflarında tarih dersi 3 saat okutulacaktır."Matematik- fizik alanında" yükseköğretime hazırlayan programlar ile "tabii bilimler" alanında yükseköğretime hazırlayan programların 10. sınıfında yer alan "tarih" dersi teknik lise program taslaklarında yer almayacak 9 ve 11. sinıflarda ortak ders olarak yer alan tarih dersi ile yetinilecektir. Bütün liselerde -modern fen ve matematik programı uygulayanlar hariç- uygulanacak haftalık ders dağılım çizelgesinde tarih dersinin saat olarak dağılımı da aşağıdaki gibi gerçekleşmiştir. Buna göre tarih dersi; fen ve edebiyat bölümlerinin 10. sınıflarında 4 saat, 11. sınıflarında ise 2 saat okutulacaktır. Modern fen ve matematik programı uygulayacak lise- 
lerde tarih dersinin saat olarak dağılımı aşağıdaki gibi gerçekleşmiştir. Fen ve Edebiyat Bölümlerinin 10. sınıfında tarih dersi 4 saat, 11. s1nıflarında ise 2 saat görülmesi karara bağlanmıştır. Ülkemizde liselerde genel olarak tarih derslerine -seçmeli tarih dersleri dışında- 2 saatlik bir dilim ayrılmıştır. Ancak ders programına baktığımızda 9. sınıf Tarih Ders Müfredatı Tarih Bilimine Giriş ünitesi ile başlamakta ve ardından tarihî çağlara giriş ile devam ederek 12. sınıf Çağdaş Türkiye ve Dünya Tarihi dersinin son ünitesi olan küreselleşen dünya ile sona ermektedir. Ve soyut bir kavram olan tarih bilimi ile her sınıfta 2 saat olmak üzere 4 sene boyunca yaklaşık 5500 yıllık bir zaman diliminde olanlar öğretilmeye çalışılır. Özünde öğrencilerin soyut düşünme becerilerini geliştirme, araştırma ve sorgulamaya dayalı bir eğitim programı uygulanırken mevcut ders saatlerinin azlığı ve buna paralel olarak müfredatın yoğunluğu göz ardı edilmektedir. Matematik ve fen derslerinin saatleri yeni program ile arttırılmışken sosyal derslerin ders saati sayılarının aynen bırakılması veya azaltılması sosyal bilimler derslerinin diğer dersler karşısındaki öneminin tartışılmasına neden olmaktadır (Yıldız, 2003, s.182).

Günümüzdeki durum ise; 9 ve 10. sınıf tarih dersi 2 saat, 11. sınıf T.C. İnkılâp Tarihi ve Atatürkçülük dersi 2 saat, 12. sınıf Çağdaş Türkiye ve Dünya Tarihi dersi 2 saat olarak planlanmıştır. Günümüz tarih ders saatleri ile geçmişteki saatlerini karşılaştırmamız gerekirse tarih derslerine ayrılan sürenin geçmişte daha fazla olduğunu söylemek mümkündür. 


\section{Sonuç}

Türkiye'de eğitimde sürekli yenilenmeyi amaç edinen şûralar, gündeme getirilen konular ve eksikliklerin giderilmesi yönünde alınacak tedbirlere göre biçimlenen tartışmalardan-kararlardan oluşmuştur. 1939 yılı itibari ile toplanmaya başlanan Maarif Şûraları Cumhuriyete geçiş döneminde yaşanan ve vatandaşlara aşılanmak istenen yeni sistemin yeni değerlerine temel oluşturmuş ve ilk şûradan itibaren çerçevesi biraz esnese de genel olarak Türkçülük temelli bir eğitim ve bu eğitim paradigması dâhilinde de tarih eğitimi inşa edilmiştir.

1939-2010 yılları arasında on sekiz kez toplanan Millî Eğitim Şûrası'ndan sadece beşinde tarih eğitimine yönelik görüşmeler yapılmıştır. Tartışılan konulara niceliksel ve niteliksel açıdan bakılıp alınan kararlar göz önüne alındığında İkinci Maarif Şûrası diğerlerinden ayrılmaktadır. 1943 yılında, İkinci Dünya Savaşı'nın sürdüğü dönemde toplanan II. Maarif Şûrası'nda -belki de- günümüzde dahi hâlâ tartışılan konular gündeme getirilerek dönemin oldukça ilerisinde kararlara imza atılmıştır. Bu şûrada tarih eğitimi program-ders kitapları ve öğretmen eğitimi âdeta revize edilmek istenmiştir. Şûrada çok çarpıcı tartışma ve kararların alındığı görülmüştür. 1940'ların ilk yarısında daha eğitim ve öğretimde çocuk merkezli anlayışlar yeni yeni literatüre hâkim olmaya başlamasına rağmen II. Maarif Şûrası'nda tarih müfredatının ve ders kitaplarının öğrencilerin bilişsel gelişimlerine nasıl uygun düzenlenmesi gerektiği konuları işlenmiştir. Ancak 1949 yılında toplanan Dördüncü Maarif Kongresi'nde aynı sorunların dile getirildiği saptanmıştır. Bu durum da akıllara II. Maarif Şûrası'nda tarih müfredatı ile 
ilgili alınan kararların uygulama aşamasına geçirilemediğini akla getirtmiştir.

Özellikle tarih ders kitapları bölümünde vurgulanması gereken nokta ise yine II. Maarif Şûrası'nda tartışılan, tarih kitaplarının Cooperation Intellectuelle kararlarına uygun yazılma girişimidir. Ancak Sadrettin Celal Antel tarafından teklif edilen bu konu Enver Ziya Karal tarafından reddedilmiş, gerekçe olarak da tarih kitaplarının yazımında "Büyük Şef"in tavsiyelerinin etkili olduğu gösterilmiştir. Siyasetin farklı kutuplara ayrılmaya başladığı bu dönemde Türkçülük-Hümanizm temelli eğitim tartışmalarının olduğu görülmektedir.

Diğer materyaller bulgusunda 19. yüzyılda Avrupa'da verilen tarih eğitiminde önemi kavranmış olan ancak hâlâ günümüzde gerek tarih öğretmeni adaylarına üniversitelerde verilen eğitimde gerekse öğretmenler tarafından okullarda verilen eğitimde hak ettiği yeri bulamamış olan senkronik tarih tablolarının kullanımı önerilmiştir. Buna ek olarak yeni tarih müfredatı ile eğitim kurumlarında yer almaya başlayan görsel malzemelerin -1943 yılında kullanımı ile resim koleksiyonları, projeksiyon makinesi ve camı, radyo- sözü edilen dönemde önemi vurgulanmış, bir anlamda öğretim teknolojilerinin öğretmenler tarafından azami düzeyde kullanılması tavsiye edilmiştir.

Tarih öğretmenlerinin eğitimi konusu ise yine ilk olarak İkinci Maarif Şûrası'nda görüşülmüss, tarih öğretmeni adaylarının "tarih âlimleri"nden ayrı bir müfredata tâbi tutulması gerektiği vurgulanmıştır. Bu bağlamda önemli olan nokta tarih bilmek-tarih öğretmek ayrı- 
mının farkına varılmasıdır. Bu ayrımın bugün bile hakkıyla yapılamayarak tarih öğretmenlerinin eğitim fakültesinde kendilerine has bir programla yetiştirilmesinin gereğine inanılmadığını gösteren YÖK uygulamalarının olması öğretmen yetiştirme konusunda Osmanlı'dan bugüne elde edilen büyük birikimin dikkate alınmayışının üzücü bir göstergesi sayılabilir. Bugün fen edebiyat fakültesinde tarih bilimini "tarihçi”" olmak için öğrenen mezunlara hiç de plânlı ve verimli olmayan, hatta kâğıt üzerinde göstermelik sayılabilecek bir planlamayla son 2,5 yıldır gerçekleştirilen "pedagojik formasyon" uygulamaları bunlardandir.

Sonuç olarak, Cumhuriyet tarihinde toplanan on sekiz şûrada -ki yeniden ifade etmek gerekirse bu şûraların tarih eğitimi açısından en önemlisinin II. Maarif Şûrası olduğu açıktır- alınan tavsiye kararlardan büyük bir kısmı uygulanarak günümüze kadar geçerliliğini korumuştur. Ancak tarih ve tarih eğitimi, değişen dünya, yapılan araştırmalar, yeni kuramlar, "yurttaşlardan” yeni beklentiler ve -belki de- siyasi tarihi şekillendiren yeni siyasetçiler açısından bakıldığında, her yeni dönemde tartışmaya açık bir konu olduğu gibi günümüzde ve gelecekte de tartışılmaya ve değiştirilmek istenmeye devam edecektir.

\section{Kaynakça}

Andraess, E. (1939). Çocuğa uygun tarih tedrisatı. (K. Kaya, Çev.). İstanbul.

Aktaş, Ö. (2012). Tarih ĕgitiminde savaş ve barış: ortaögretim öğrencilerinin savaş ve barış konularıla ilgili bilgilerinin ve tutumlarının çeşitli değişkenler açısından değerlendirilmesi. Yayınlan- 
mamış doktora tezi, Gazi Üniversitesi.

Aktekin, S. (2010), Yeni sosyal bilgiler ve tarih dersi programlar1, öğretmen eğitimi ve toplumsal barış. Eğitim, Çatışma ve Toplumsal Barış: Türkiye'den ve Dünyadan Örnekler, 104-112.

Aslan, E. (2011a). 1924 ilk mektepler müfredat programı. İlkögretim Online, 10(2), 717-734.

Aslan, E. (2011). Osmanlı’nın “mekatib-i iptidaiye” sinden Türkiye Cumhuriyeti'nin “ilk mektepler" ine geçişte tarih programlarında değişim. Ankara Üniversitesi Türk İnklâp Tarihi Enstitüsü Atatürk Yolu Dergisi, 12(48), 749-777.

Aslan, E. (2012a). Atatürk döneminde tarih eğitimi- I: “Türk tarih tezi” öncesi dönem (1923-1931). Ĕ̈itim ve Bilim, 37(164), 331-346.

Aslan, E. (2012b). İmparatorluktan cumhuriyete geçiş sürecinde ortaöğretim tarih programlarında değişim I: Ortamektep. International Periodical For the Languages, Literature and History of Turkish or Turkic, 7(2), 99-128.

Ata, B. (2001). Müzeler ve tarihî mekanlarla tarih ögretimi: tarih öğretmenlerinin "müze eğitimi'ne" ilişkin görüşleri. Yayınlanmamış Doktora Tezi, Gazi Üniversitesi Eğitim Bilimleri Enstitüsü.

Ata, B. (2008). 1943'teki “İkinci Millî Eğitim Şurası'nın” tarih eğitimi kararlarından birinin uygulanması: Bir Histomap’in öyküsü. Kuram ve Uygulamada Eğitim Bilimleri, 8(2), 335-353.

Baymur, F. (1949). Tarih öğretimi. Ankara: Recep Ulusoğlu Basımevi.

Copeaux, E. (2006). Tarih ders kitaplarında (1931-1993) Türk tarih tezinden Türk - İslam sentezine. İstanbul: İletişim Yayınları.

Coşkuner, E. (2008). Barış eğitimi programının öğrenci şiddeti üzerindeki etkilerinin incelenmesi. Yayınlanmamış yüksek lisans tezi, Dokuz Eylül Üniversitesi Eğitim Bilimleri Enstitüsü.

Çapa, M. (2002). Cumhuriyet'in ilk yıllarında tarih öğretimi. Ankara Üniversitesi Türk Inkllâp Tarihi Enstitüsü Atatürk Yolu Dergisi, 
29(30), 39-55.

Çelikkaya, T. (2011). Sosyal bilgiler programında yer alan becerilerin kazandırılma düzeyi: öğretmen görüşleri, Kastamonu Ĕ̆itim Dergisi, 19(3), 969-990.

Dinç, S. (Tarihsiz). Cumhuriyet dönemi ĕgitim tarihimizde II. Milli Ĕ̈itim Şûrası (15 - 21 şubat 1943) ve uygulamaları.

Doğan, Y. (2008). Sosyal bilgiler öğretiminde tarihsel yazılı kanıt kullanmanın öğrencilerin akademik başarısına etkisi. Türkiye Sosyal Araştırmalar Dergisi, 12(2), 171-186.

Karasar, N. (2005). Bilimsel araştırma yöntemleri. Ankara:Nobel Yayın Dağıtım.

Meb (2007). Tarih Dersi Öğretim Programı (9.Sınıf). Ankara: MEB Talim Ve Terbiye Kurulu Başkanlığı.

Öztaş, S. (2007). Tarih öğretimi ve filmler: "tarih öğretiminde film kullanılmasının öğrenci başarısı üzerine etkisi”. Yayınlanmamış doktora tezi, Gazi Üniversitesi Eğitim Bilimleri Enstitüsü.

Safran, M. ve Ata, B. (1996). Barışçı tarih öğretimi üzerine çalışmalar; Türkiye'de tarih ders kitaplarında Yunanlılar'a ilişkin kullanılan dil ve öğrenci görüşleri. Gazi Eğitim Fakültesi Gazi Üniversitesi Dergisi, 16(1), 11-26.

Şimşek, A. (2001). Tarih öğretiminde efsane ve destanların rolü. G.Ü. Kırşehir Eğitim Fakültesi Dergisi, 2(3), 11-21.

Şimşek, A. (2004). İlköğretim okulu sosyal bilgiler dersi tarih konularının öğretiminde hikâye anlatım yönteminin etkililiği. Türk Ĕ̈itim Bilimleri Dergisi, 2(4), 495-509.

Şimşek, A. (2006). Tarihsel romanın eğitimsel işlevi. Bilig, 37, 65-80.

Şimşek, A. (2006). Illkögretim öğrencilerinde tarihsel zaman kavramının gelişimi ve ögretimi. Yayımlanmamış doktora tezi, Gazi Üniversitesi Eğitim Bilimleri Enstitüsü. 
Şimşek, A. ve Satan, A. (2011). Milli tarihin inşası: Makaleler. İstanbul: Tarihçi Kitabevi.

Şimşek, A. (2011). Geçmişin nesnesini arayan bilim arkeoloji: Türkiye'de tarih öğretimindeki durumu. Turkish Studies, 6(2), 919-934.

Şimşek, A. ve Koca, F. (2012). Lise tarih ders kitaplarında uzlaşma kültürü. Marmara Üniversitesi "Değişsen Dünyada Vatandaşlık ve Demokrasi Eğitiminde Yeni Yönelimler ve Sorunlar" Uluslararası Sosyal Bilgiler Eğitimi Sempozyumu, İstanbul.

Toprak, Z. (2012). Darwin'den Dersim'e Cumhuriyet ve antropoloji. İstanbul: Doğan Kitap.

Üstel, F. (2004). "Makbul vatandaş"ın peşinde, II. Meşrutiyet'ten bugüne vatandaşlı eğitimi. İstanbul: İletişim Yayınları. 